\title{
The protective effects of ginseng plant extract (ginsana) and garlic powder against the bad effects of lambda-cyhalothrin insecticide on kidneys of female rats
}

\author{
Mouchira M. Mohi-Eldin ${ }^{1}$, Amna M. Mostafa ${ }^{2}$ and Aml A. Abd- El kader ${ }^{2}$ \\ 1-Department of pathology and Clinical pathology, Faculty of Veterinary \\ Medicine, South Valley University, Qena. \\ 2- Department of Zoology, Faculty of Science, South Valley University, Qena.
}

\section{ABSTRACT}

Ginseng and garlic are well known plants which have anti oxidant effects. The present study investigates the protective effects of ginseng extract and garlic powder on the bad effects of lambda-cyhalothrin insecticides (LTC). Eighty female Wister rats divided into 4 groups as follow; group (1) control group, group (2) injected with(9.3 mg/kg b.wt) LTC alone, group (3) injected with(200 mg/kg b.wt) ginseng extract (G115) followed by $(9.3 \mathrm{mg} / \mathrm{kg}$ b.wt) LTC, group (4) injected with (100 $\mathrm{mg} / \mathrm{kg} \mathrm{b.wt}$ ) garlic extract (GA) followed by $(9.3 \mathrm{mg} / \mathrm{kg} \mathrm{b}$.wt) LTC All groups were injected intraperitonialy for 15 days (as a short term) and 21 days (as along term).

Histological examination of the kidney sections showed severe congestion, besides cloudy swelling in the proximal and distal convoluted tubules, vacuolar degeneration with necrosis. In addition to edema in the bowman's space, hypercellularity and destruction with renal casts detected in some of renal tubules in animal injected with LTC only for 15 days. While rats injected with LTC for 21 days revealed thickening and edematous in the wall of the blood vessels with proliferation in the endothelial cells, besides thrombosis and hemorrhage. Chronic interstitial nephritis in most rats and perivasculitis were detected. Kidneys of rats pretreated with ginseng followed by LTC for 15 days showed protective effect in the form of disappear of the edema of bowman's space and cloudy swelling except some necrosis and slight congestion. Whereas 21 days showed high protective effects by reducing of cloudy swelling and necrosis. Garlic also diminished the pathological alterations in the kidneys but lower than ginseng.

Histochemical observation revealed, increases in the protein inclusion in rats injected with $(9.3 \mathrm{mg} / \mathrm{kg}$ b.wt) lambda-cyhalothrin alone in comparison with control, while ginseng and garlic groups almost have normal protein inclusion distributions to some extant.

Key words: Lambda-cyhalothrin (LTC) - Ginseng (G115) - Garlic (GA) - Histology- Histochemistry.

\section{INTRODUCTION}

Lambda-cyhalothrin is effective and persistent activity against a large variety of arthropods harmful both to human and animal health, and to vegetal production (who, 1990). LTC is widely used in veterinary products to control lices, flies, and ticks on cattle, sheep, and pigs, as well as used in agricultural formulations to control numerous insect pests on fruits, vegetables, and field crops (leahey, 1985; schenone and rojas, 1992; davies et al., 2000 and kroeger et al., 2003). when given lambda-cyhalothrin to experimental animals at $668 \mathrm{ppm}$ in the drinking water during 21 days showed multiple foci of hemorrhage, tubular dilatation of proximate tubules, 
tubular cell desquamation, inflammatory cell infiltration and cloudy swelling of tubules in the kidneys (Fetoui et al ., 2009). Cirrhinus mrigala fish when exposed to lambda-cyhalothrin at $0.3 \mathrm{ppb}$ and $0.6 \mathrm{ppb}$ LTC exhibited cloudy swelling of epithelial cells of renal tubules, necrosis in tubular epithelium, contraction of the glomerulus's and expansion of space inside the bowman's capsule (Velmurugan et al., 2007). Other researches showed many pathological alteration induced by lambdacyhalothrin administration (Abdul basir et al., 2011 ;Sakr et al , 2001; Abu EI-Zahab et a1., 1993 Abou-Zeid and EI-Balshy, 1995; Abdeen et al., 1994 and Parken et al., 1986).

Panax ginseng (C.A. Mayer) which is the protective material in the present work is the most famous plant of all Asian medicinal plants. Panax derives from Greek roots, pan meaning "all" and akos, "cure," referring to the "cure all". Ginseng used in China for over 2,000 years, much of the research has provided a scientific basis for the traditional claims for ginseng use. Ginsengs have some protective effects against toxic substances as reported by (Abdel-Fattah et al., 2010; Fatma, 2002 and 2003).

Garlic (Allium Sativum) which is the second protective material in the present study is a common food spicy used all over the world. Garlic were studied by (Chung, 2006) which described the role of garlic organosulfur compounds in free radical scavenging. Omurtag et al., 2005; Chaverri et al., 2008 and Wongmekiat et al., 2004 noted that garlic and garlic extracts used for millennia in folk medicine and reported to provide protection against free radical damage in the body through their antioxidant activities.

\section{MATERIAL AND METHOD}

\section{Chemicals:}

\section{1-Lambda-cyhalothrin:}

Empirical formula: $\left(\mathrm{C}_{23} \mathrm{H}_{19} \mathrm{ClF}_{3} \mathrm{NO}_{3}\right)$. Its commercial name called Lambda super fog and chemical name is [ $\alpha$-cyano-3-phenoxybenzyl-3-(2-chloro- 3, 3, 3-trifluoro-1propenyl)-2, 2-methylcyclopropanecarboxylate] (LTC). It is a synthetic pyrethroid, yellow-brown viscous liquid with a mild odor. It obtained from Adwia industries company, Egypt.

LD50 of LTC $=56 \mathrm{mg} \backslash \mathrm{kg}$ for female rat (Extension Toxicology Network) Structural formula of lambda-cyhalothrin:
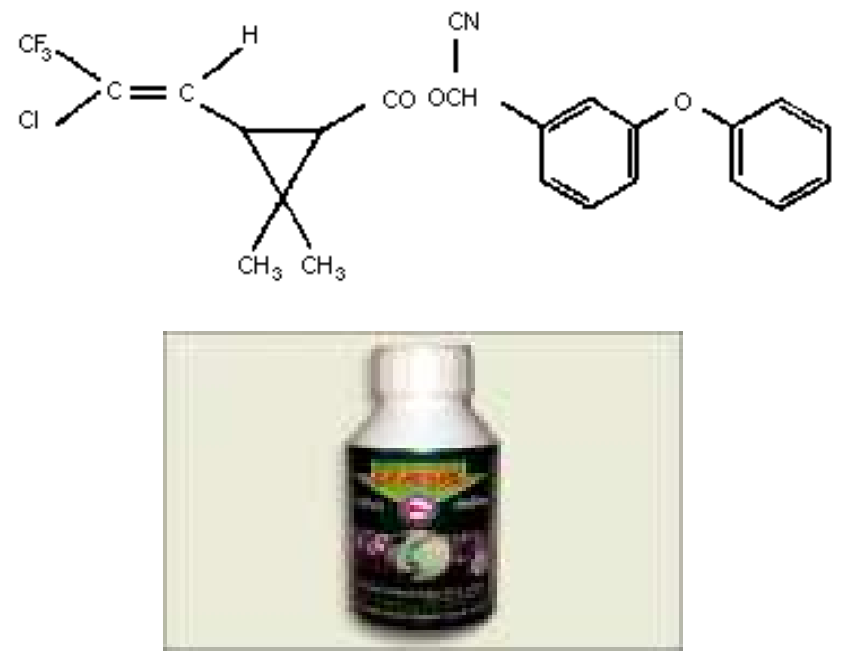
2-Panax Ginseng (GINSANA) (G115):

Panax Ginseng (G115) was purchased from EIPICO Pharmaceutical Company, Egypt.
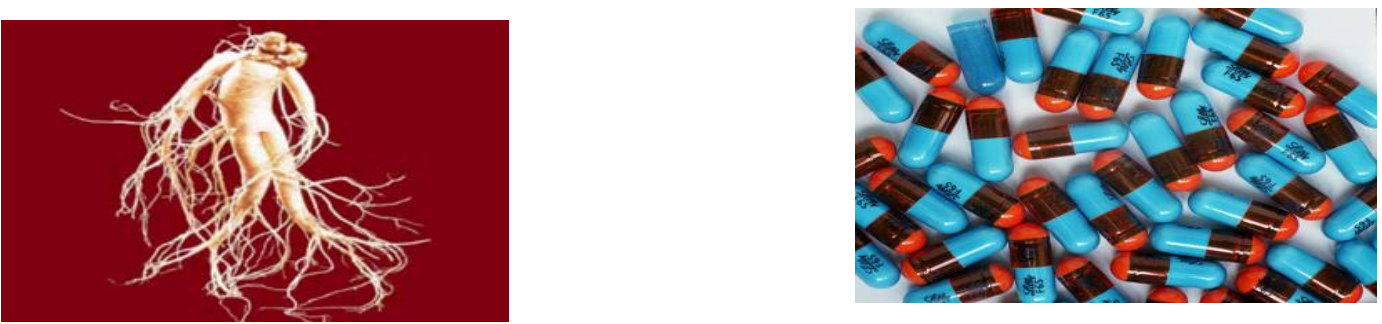

Photograph of Panax Ginseng plant

3-Garlic (Allium Sativum) (GA):

The garlic plant (Allium Sativum) (GA) was purchased as a powder from National Foods Company, Egypt.
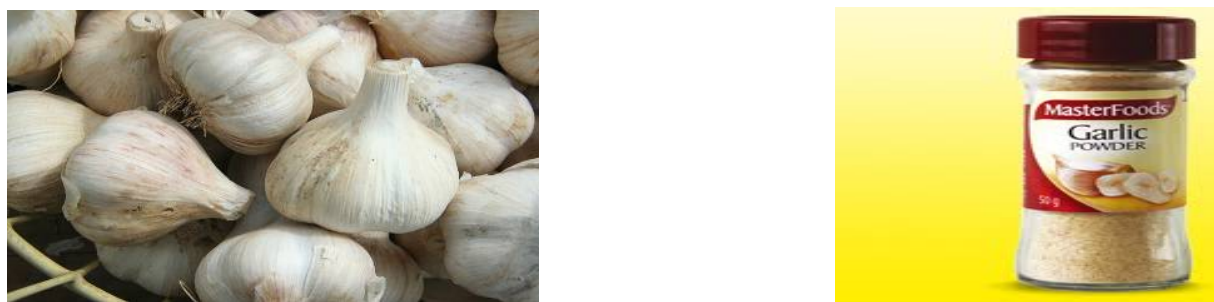

Photograph of garlic cloves

\section{Animals:}

Eighty adult female albino rats weighing $200 \pm 20$ gm at age 4 months. The animals were obtained from Abu Rawash breeding House, Giza, Egypt. Animals divided into 4 groups.

\section{Experiment design}

Each group was divided into two subgroups (A \& B), 10 rats in each subgroup. Group (1): injected intraperitoneally with normal saline solution and used as a control. Group (2): injected intraperitoneally with lambda-cyhalothrin at $9.34 \mathrm{mg} / \mathrm{kg} \mathrm{b}$.wt. Group (3): injected intraperitoneally with panax ginseng at $(200 \mathrm{mg} / \mathrm{kg})$ followed by lambda-cyhalothrin at $9.34 \mathrm{mg} / \mathrm{kg}$ b.wt. Group (4): The rats injected intraperitoneally with garlic $(100 \mathrm{mg} / \mathrm{kg})$, followed by lambda-cyhalothrin at $9.34 \mathrm{mg} / \mathrm{kg}$ b.wt. Animals of subgroups (A) were sacrificed after 15 days of treatment and Animals of subgroups (B) were sacrificed after 21 days of treatment. Specimens from the kidneys, from the sacrificed animals were collected, then fixed in $10 \%$ neutral buffered formalin and embedded in paraffin wax. Sections about $5 \mu \mathrm{m}$ thickness were prepared and stained with H\&E for histopathological examinations according to Drury and Willington, (1980). Specimens from kidneys were fixed in formol alcohol for histochemical examination, dehydrated in ascending concentrations of ethanol, then cleared in methylbenzuate and embedded in paraffin wax. Sections $5 \mu$ thick were prepared and stained with bromophenol blue (BP) for protein demonstration according to (Mazia et al., 1953).

\section{RESULTS}

\section{I-Histopaholoical Results \\ The Insecticide Toxicity:}

Kidneys of control rats seen in the normal structure .The cortex consisted of normal renal corpuscles (glomeruli) with adjacent proximal and distal convolution of 
nephrons (the epithelial cells in both appeared with normal architecture, besides normal cells displayed in the collecting tubules in the medulla (Fig. 1, A). Injection with $(9.3 \mathrm{mg} / \mathrm{kg})$ lambada-cyhalothrin LTC daily for 15 days as a (short term) showed severe congestion in renal and glomerular capillaries, besides cloudy swelling in the proximal and distal convoluted tubules. Vacuolar degeneration with necrosis showed in some renal tubules in the cortex. In addition to, edema in the bowman's space caused pressure atrophy on the glomerular tuft (Fig. 1, B). In other hand, hypercellularity showed in most glomeruli. Destruction with renal casts detected in some of renal tubules, while kidneys of (subgroup B), showed congestion in glomerular and renal blood vessels. Thickening and edematous was detected in the wall of the blood vessels with proliferation in the endothelial cells, manifested with endotheliosis, besides thrombosis and hemorrhage. Edema displayed in the bowman's space resulting in pressure on the glomerular cells. Chronic interstitial nephritis in most rats, manifested with severe aggregation of the inflammatory cells (mainly macrophages cell, lymphocytes and fibroblast) replaced large areas of the degenerated renal tubules (Fig. 2, B). Cloudy swelling showed in all tubular cells, causing atrophy in the glomeruli, besides destruction in some of the tubules. Perivasculitis characterized destruction and edematous in the wall of blood vessels with aggregation of round cells mainly macrophage cells surrounded it.

\section{Ginseng Protective Effect:}

Ginseng has protective effect more than garlic. Pretreated with ginseng LTC for 15 days showed reduced in, the histopathological alteration induced by LTC in the form of normal glomeruli and disappearance of edema except moderate necrosis in the other of the glomerular tuft. Mild fibrous tissue proliferation showed among the degenerated renal tubules. Slight Congestion in some of renal blood vessels in cortex and medulla were detected. Focal areas of the necrotic tubules (Fig.1,C)but most tubules displayed mild degeneration, wheras the 21 days treated rats with ginseng before LTC revealed that there is no Chronic interstitial nephritis, Perivasculitis or destruction in the tubules but few rats in this group showed contraction and shrinkage in glomeruli inside the bowman's space. On other hand, Hypercellularity was detected in the glomeruli in other rats (Fig. 2, C). Cloudy swelling was seen in the renal tubules in few rats. Slight Congestion was detected in the renal blood vessels in some rats. Necrosis was noticed in a few renal cells in the collecting tubules.

\section{Garlic Protective Effect:}

Garlic have some protective effect observed in diminishing the sever changes in the kidneys tissues caused by (LTC), so that pretreated with garlic before(LTC) for 15 days revealed there is no edema but the cortex has moderate destruction and necrosis in some of renal tubules with renal casts in other (Fig.1,D), besides few fibrous tissues proliferated among it. Thickening in the wall of the congested blood vessels was noticed. Moderate swelling in the epithelial lining showed in most of the renal tubules in the cortex compressed on the glomeruli which appeared congested in the glomerular capillary. Hypercellularity and congestion were seen in the glomeruli. Whenever 21 days treated rats with garlic showed that most of the collecting tubules appeared apparently normal with renal casts in few cells with regeneration the epithelial cells of the tubules but congestion in the glomerular blood vessels was seen in the cortex of some rats. Mild dilation in some of renal tubules (Fig. 2, D) but the remaining tubules appeared normal. Few inflammatory cells scattered among renal tubules. 


\section{HISTOCHEMICAL RESULTS}

Normal distribution of protein inclusion was observed in the normal kidney section. The glomerular tuft and the basal lamina of the different types of the tubules are denoting their richness in this inclusion that appears as bluish granules with broom phenol blue. While the nuclei of all component cells, and the brush borders of the proximal convoluted tubules appeared moderately stained (Fig. 3, A). I5 Days following the application of repeated $(9.3 \mathrm{mg} / \mathrm{kg}) \mathrm{b}$. wt of (LTC), an obvious increase sign of protein content mainly in the glomerular tuft, the basal lamina of the different types of the tubules (proximal, distal and collecting tubules) (Fig3, B), while treated with LTC for 21 days showed slight increase in the protein content in the basal lamina of the different types of renal tubules unlike the group treated 15 days (Fig. 4, B).

The kidneys section examined after treatment with ginseng extract (G115) used as protective material followed by(LTC) for 15 days, showed redundant sign of protein level improvement mainly in the glomerular tuft and distal tubules comparing with the treated one and control one (Fig3, C), while ginseng extract (G115) followed by LTC for 21 days brought into vision a certain develop the picture of normal distribution of protein materials in the kidneys tissue to some extant comparing with those treated with LTC alone(Fig. 4, C).

The kidneys section of the experimented animals that received the other protective material (garlic) followed by LTC for 15 days were found to have acquired a few of the protein figure of the normal one. Normal distribution of protein was observed only in the glomarular tuft and the basal lamina of the proximal convoluted tubules that appeared moderately stained(Fig3, D), while rats treated with garlic followed by LTC for 21 days showed no variation in the protein content was observed comparing between those treated with LTC or control group(Fig. 4, D).

\section{DISCUSSION}

Pathologically, in the present study the kidneys in group treated with (LTC) alone for 15days showed severe congestion in renal and glomerular capillaries, besides cloudy swelling in the proximal and distal convoluted tubules. Vacuolar degeneration with necrosis showed in some renal tubules in cortex. Edema in the bowman's space causing pressure atrophy on the glomerular tuft. In other hand, hypercellularity showed in most golmeruli. Destruction with renal casts detected in some of renal tubules. While, in 21 days showed mild congestion in glomerular and renal blood vessels. Focal areas of macrophage cells replaced the necrotic renal cells with destruction in the renal blood vessels resulting in hemorrhage. Thickening and edematous in the wall of the blood vessels with proliferation in the endothelial cells, manifested with endotheliosis, besides thrombosis. Edema displayed in the bowman's space resulting in pressure on the glomerular cells. Interstitial nephritis in most rats manifested with severe aggregation with inflammatory cells among the degenerated renal tubules. Cloudy swelling showed in all tubular cells causing atrophy in the glomeruli, besides destruction in some tubules. Perivasculitis characterized with aggregation of mononuclear mainly macrophage cells surrounded the blood vessels. Vacuolation in the glomerular cells and dilation in the blood vessels. These results were emphasizes by Sakr and Hanafy, (2002) which recorded that the Kidneys of Toads (Bufo egularis) intoxicated with a pyrethroid insecticide "fenvalerate" dissolved in tap water at a dose level of $0.5 \mathrm{mg} / \mathrm{kg} \mathrm{b}$. wt (1/1OLDso/4 days) once per day for 3 weeks showed congestion and dilatation of the renal vessels at the first week. But at the second week of the treatment, the intertubular spaces were infiltrated 
by leucocytes, besides cloudy swelling of the renal tubules and shrinkage of the glomeruli was observed. Necrosis of the renal cells and cytoplasmic vacuolations with atrophy of the goleruli was detected at the third week of the treatment.

The present finding in the kidneys agreed with other authers in different animals and this results agreed with (Fetoui. et al., (2009) which reported that rats given lambda-cyhalothrin (668ppm) through drinking water during 21 days showed that LTC induced multiple foci of hemorrhage, tubular dilatation of proximate tubules, tubular cell desquamation, inflammatory cell infiltration and cloudy swelling of tubules in the kidney. Also among of these authers Velmurugan et al., (2007) in tissues of kidneys of Cirrhinus mrigala fishes that exposure to $0.3 \mathrm{ppb}$ and $0.6 \mathrm{ppb}$ lambda-cyhalothrin. Abdul basir et al.,(2011) found that lambda-cyhalothrin induced congestion and hemorrhage of blood vessels were seen only on serosal surface in groups B, C and D, while, renal parenchyma and stroma were free of any pathology. Abu EI-Zahab et a1., (1993) found that kidneys of rats inhaled pyrethroids induced congestion of blood vessels, hemorrhage, necrosis and inflammatory leucocytes. Abdeen et al., (1994) reported that treating mice with fenvalerate induced renal damage of the epithelial lining of the renal tubule, ruptured of the distal tubules and enlargement of the glomerulei with hydropic degeneration. Abou-Zeid and EI-Balshy (1995) recorded that inhalation of Ezalo (a synthetic pyrethroid) caused acute tubular necrosis and glomerulonephritis in kidneys of new born mice. Parken et al., (1986) observed that sub chronic feeding of decaboxy fenvalerate induce glomerulonephrosis in kidney of rats. Sakr et al., (2001) found that inhalation of tetramethrin showed many histopathological changes in the kidney of rats. Tamang et al .,(1991) reported that acute cypermethrin toxicity in Black Bengal goats by drenching cypermethrin at $600 \mathrm{mg} / \mathrm{kg} \mathrm{b}$. w kidneys showed necrosis of lining epithelial cells of proximal convoluted tubules.

In present study Group 3; pretreated with ginseng extract improve toxic effects of LTC in the kidneys due to their anti oxidant effects .This results revealed by (Chang et al,. 1999) which stated that ginseng can induce the antioxidant enzymes which are important for maintaining cell viability by lowering the level of oxygen radical generated from intercellular metabolism.

Also, Group 4; pretreated with garlic have some protective effects against LTC toxicity through their antioxidant effects previously noted by (Chung, 2006) which described that the role of garlic organosulfur compounds in free radical scavenging. Allicin is a major component of garlic organosulfurs and its antioxidant properties has already been confirmed. In addition to allicin, other garlic organosulfurs, such as alliin, allyl cysteine, allyl disulfide and diallyl disulfide have antioxidant properties and can neutralize several types of reactive oxygen species.

Omurtag et al., (2005) noted that garlic and garlic extracts used for millennia in folk medicine and reported to provide protection against free radical damage in the body through their antioxidant activities.

Histochemically, Kidneys of treated rats for 15 days with LTC showed an obvious increase sign of protein content mainly in the glomerular tuft, the basal lamina of the different types of the tubules (proximal, distal and collecting tubules), the nuclei of all component cells, and the brush borders of the proximal convoluted tubules, whereas animals treated for 21 days showed slight increase in the protein content of the basal lamina of the different types of renal tubules unlike the group treated 15 days.

(Group 3); showed that animals treated with ginseng prior to LTC for 15 days revealed redundant sign of protein level improvement mainly in the glomerular tuft 
and distal tubules comparing with the normal group, while the application of LTC plus G115 daily for 21 days has brought into vision a certain develop the picture of normal distribution of protein materials in the kidneys tissue to some extant comparing with those treated with LTC alone.

(Group 4); treated with garlic followed by LTC for 15 days were found to have acquire a few of the protein figure of the normal one. Normal distribution of protein was observed only in the glomarular tuft and the basal lamina of the proximal convoluted tubules that appeared moderately stained compared with treated one and control one, while 21days following the utilization of LTC plus garlic, no variation in the protein content was observed comparing between those treated with LTC or control group.

\section{REFRENCES}

Abdul basir, Ahrar Khan1, Riaz Mustafa1, Muhammad Zargham Khan1, Farzana Rizvil, Fazal Mahmood1 and Arfan Yousa (2011): Toxicopathological effects of lambda-cyhalothrin in female rabbits (Oryctolagus cuniculus) Human \& Experimental Toxicology., 30(7):591-602

Abdel-Fattah, SH., M. Sanad, M., Safaa, M. A. and Ragaa F. Ghanem (2010): The Protective Effect of White Ginseng against Biochemical and Pathological Changes Induced by Aflatoxins in Rats. Journal of American Science, 6 (12).

Abu-El-Zahab, H. S., Amr M. M., Awadallah W. E. Abdel Aal and Ei-Khyat, Z. A. (1993): Physiological and histopathological studies on long-term inhalation of adult albino rats to pyrethroids III. Serum proteins, enzymes, creatinine and urea nitrogen. J. Egypt. Ger. Soc. Zool., 11:311-334.

Abdeen, A. M., T. A. M. Amer, M. EI-Habibi, M. EI-Sayed and M. Kamel, (1994): Histological and histochemical studies on the effect of fenvalerate insecticide on some organs of albino mice. J. Union Arab Biol., 2:129-166.

Abou-Zaid, F. A. and R. M. EI-Balshy, (1995): Toxic effect of Ezalo, a synthetic pyrethroid on liver, kidney and lung of newly born mice. J. Union Arab Biol., 4: 235-264.

Chaverri. J. P.; Paola, Yamcanul., Yolanda, I. Hirino., Dolores, Javier. SanchezGonzalez., Claudia, Maria. Martinez-Mnez., Ristino, Cruz., Omar, N. Medina Campos (2008): Protective effects of garlic powder against potassium di chromate-induced oxidative stress and nephrotoxicity. Food and Chemical Toxicology. 46: 619-627.

Chang, M.S.; Lee, S.G. and Rho, H.M. (1999): Transcriptional activation of Cu/Zn super oxide dismutase and catalase genes by panoxadiol ginsen -osides extracted from panax ginseng. Pytother. Res. Dec., 13 (8): 641-644.

Chung L. Y. (2006): The antioxidant properties of garlic compounds; allyl cysteine, alliin, allicin, and allyl disulfide. J. Med. Food. 2: 205-213.

Davies CR., Lanos-Cuentas EA., Campos EA., Monge J., Leon E., Canales J. (2000): Sparying houses in the Peruvian Andes with lambda-cyhalothrin protect residents against cutaneous leishmaniasis. Trans R Soc Trop Med Hyg, 94: 631-636.

Drury R. A. B. and Wallington E. A. (1980): Carleton's Histological Technique, $5^{\text {th }}$ edt. Oxford University Press. New York.

Fatma A. Morsy (2002): Protective effect of ginseng against toxic effect of ochratoxin (OA) in kidney of male rats. The Egyptian Jornal of Hospital Medicine, 7: 151-167. 
Fatma A. Morsy (2003): protective effect of vitamineCand ginseng on experimental liver and kidney injuries induced by insecticide profenphos in male rats The egyption journal of hospltal medicine. 10:34-51.

Fetoui. H., Mohamed, Makni, El Mouldi Garoui., Najiba, Zeghal (2009): Toxic effects of lambda-cyhalothrin, as synthetic pyrethroid pesticide, on the rat kidney: Involvement of oxidative stress and protective role of ascorbic acid. Experimental and Toxicologic Pathology. 62(6):593-599.

Kroeger A, Villegas E, Ordonez-Gonzalez J, Pavon E, Scorza JV (2003): Prevention of the transmission of chagas disease with pyrethroid-impregnated materials. Al J Trop Med Hyg, 68: 307-311.

Leahey J. P. (1985): Metabolism and environmental degradation. In: Leahey JP, editor. The pyrethroid insecticides. London: Taylor \& Francis .pp .263 -342.

Maulik M., Banerjee S. K. and Manchanda S. C. (2001): Garlic induced alteration in rat liver and kidney morphology and associated changes in endogenous antioxidant status. Food \& chem. Toxicol., 39: 793-797.

Mazia D., Brewer P. A. and Al- Fert M. (1953): cytochemical stain and measurement of protein with mercuric bromophenol blue. J. Biol. Buil., 104:57-67.

Omurtag G. Z., Guranlioglu F. D. and Sehirli O. (2005): Protective effect of aqueous garlic extract against naphthalene-induced oxidative stress in mice. J. Pharm. Pharmacol., 57: 623 - 630.

Parken, C. M., H. C. Wimberly, A. S. Lam, T. H. Gardiner and G.A. Van Glder, (1986): Subchrbnic feeding study of decarboxy fenvalerate in rats. J. Toxicol. Environ. Health, 18: 77-90.

Sakr, S. A and Hanafy .S.M, (2002): Histopathological alterations in the liver and kidneys of toad (Bufo regularis) intoxicated with pyrithroid insecticides. Journal of biological science 2(4): 208-211.

Schenone, RojasA. (1992): Laboratory study on the immediate and persistent insecticide activity of the pyrethroid lambda-cyhalothrin on nymphs of IV instar Triatoma infestans. BolChilParasitol, 47: 35-37.

Tamang, RK | Jha, GJ | Singh, KK (1991): Clinicopathology of acute cypermethrin toxicity in goats. Indian Journal of Animal Sciences [INDIAN J. ANIM. SCI.]. 61 (5): 493-494.

WHO, (1990): Cyhalothrin, environmental health criteria, 99, Geneva, Switzerland.

Wongmekiat, O. and Kamthorn, Thamprasert (2005): Investigating the protective effects of aged garlic extract on cyclosporin-induced nephrotoxicity in rats.Fundamental and clinical pharmacology.19:555-562.

Velmurugan. B, Mariadoss ,Selvanayagam., Elif,Cengiz and Erhan,Unlu.(2007): Histopathology of lambda-cyhalothrin on tissues (gill,kidney,liverand intestine) of Cirrhinus mrigala.Environmental Toxicology and Pharmacology .24:286-291. 

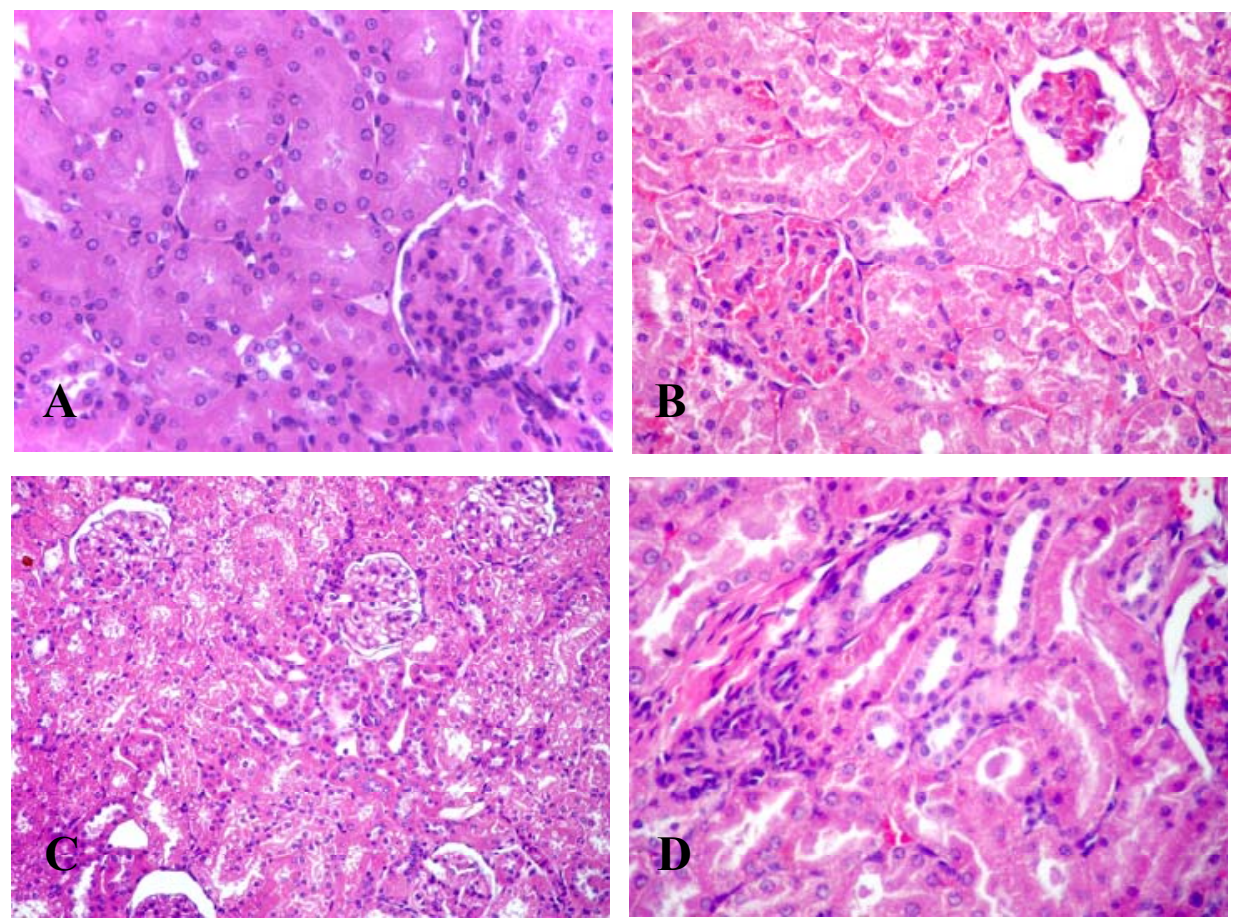

(Fig. 1): Photographs of kidneys of rats treated with LTC for 15 days, A control group, B LTC alone showing severe congestion in renal and glomerular capillaries besides cloudy swelling in the proximal and distal convoluted tubules (H\&E., x 300), C Ginseng +LTC showing focal areas of the necrotic tubules but most tubules displayed mild degeneration (H\&E., x 300), D Garlic + LTC showing moderate destruction and necrosis in some of renal tubules with renal casts, besides few fibrous tissues proliferated among it (H\&E., x 300).
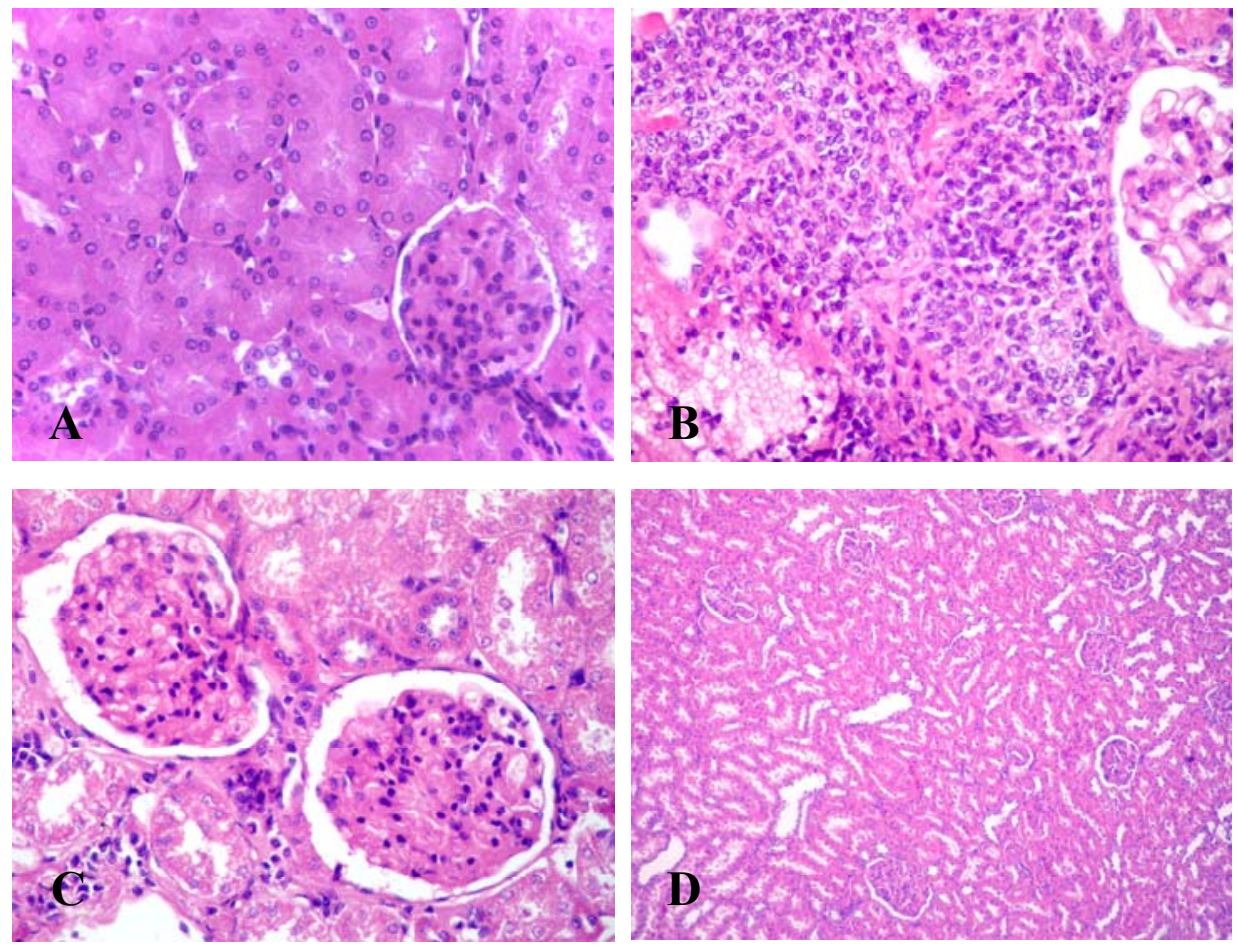

(Fig. 2): Photographs of rats treated for 21 days with LTC, A control group, B LTC alone showing chronic interstitial nephritis in most rats. (H\&E., x 300), C Ginseng + LTC the kidneys, showing hypercellularity in the glomeruli (H\&E., x 300), D Garlic + LTC showing mild dilation in some of renal tubules (H\&E., x 150). 

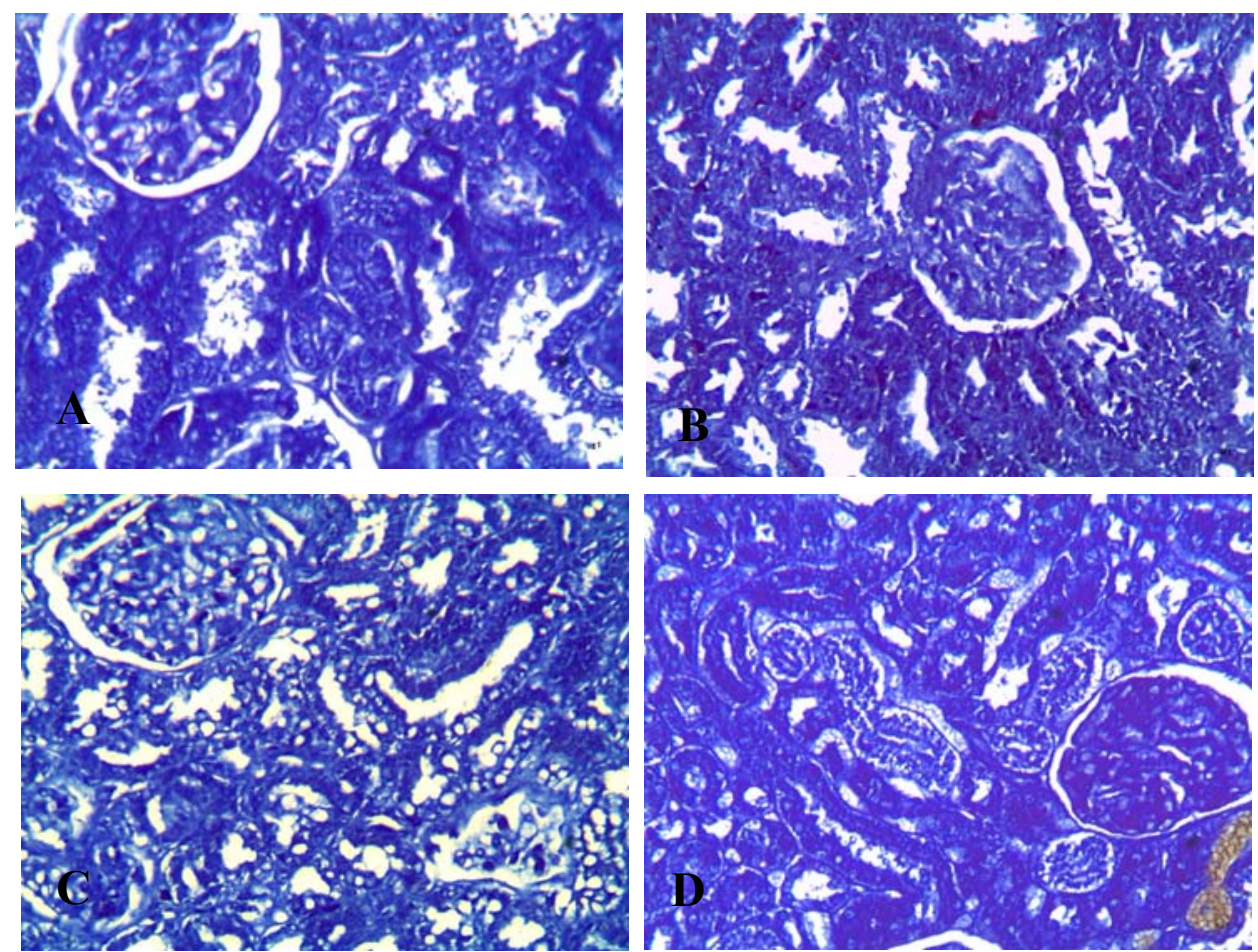

(Fig. 3): Photographs of kidneys of rats treated with LTC for 15 days, A control group showing normal protein inclusion, B showing LTC alone showing increase in protein inclusion, C ginseng + LTC showing decrease in protein inclusion compared with LTC alone, D garlic +LTC showing normal distribution of protein only in the glomarular tuft. The basal lamina of the proximal convoluted tubules that appeared moderately stained. (Bromo phenol blue X400)
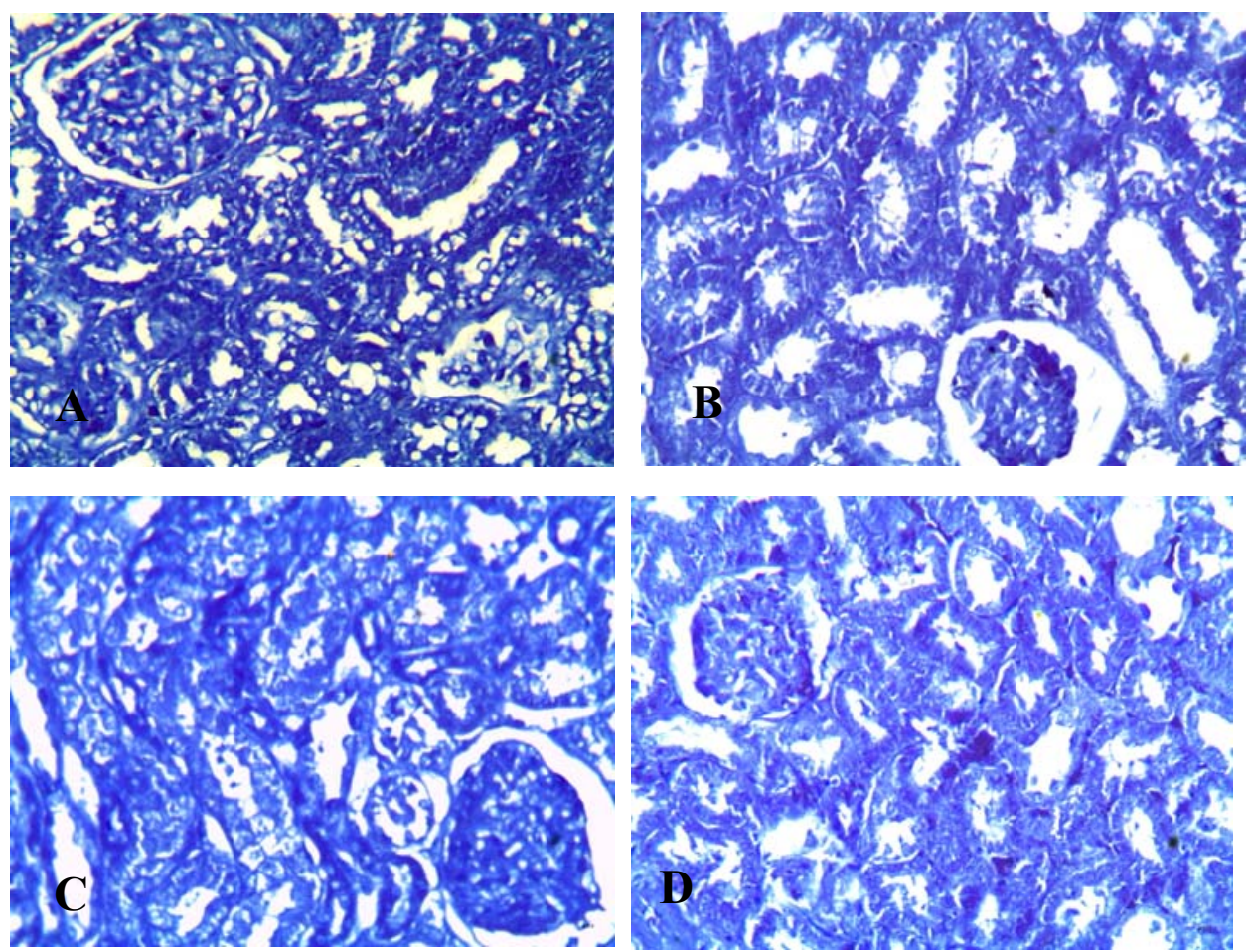

(Fig4): Photographs of kidneys of rats treated with LTC for 21 days, A control group showing normal protein inclusion, B LTC alone showing slight increase in the protein content, C ginseng +LTC almost normal distribution of protein content, D garlic $+\mathrm{LTC}$ no variation in the protein content comparing between those treated with LTC. (Bromo phenol blue X 400) 


\section{ARABIC SUMMARY}

"التأثير الوقائي لمستخلص نبات الجنسنج (جنسانا ) وبودرة الثوم ضد التأثيرات الضارة لمبيد (لمبادا-

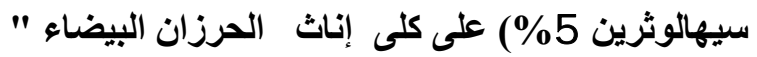

مشيرة محمد محيى الدين, 1أ منة محمد مصطفى , أمل احمد عبد القادر 2

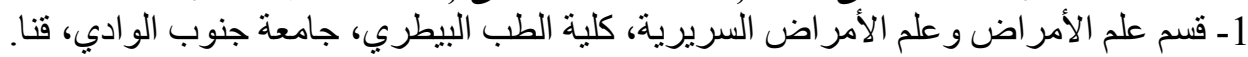
2 - قسم علم الحيوان، كلية العلوم، جامعة جنوب الوبر الو ادي، قنا.

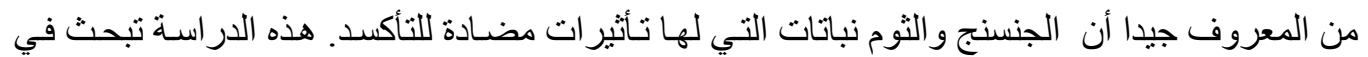

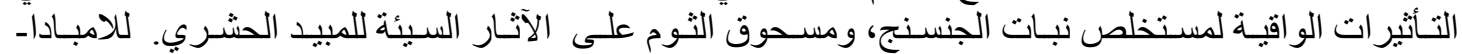

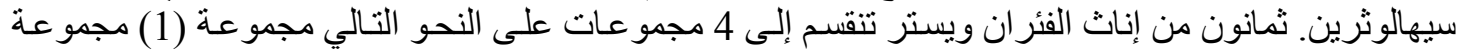

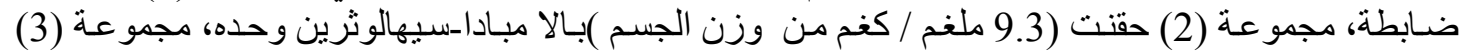

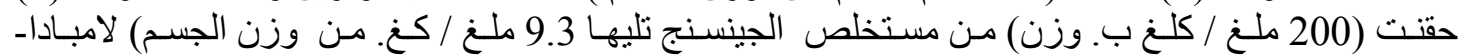

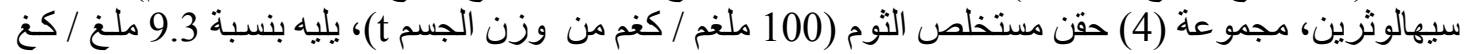

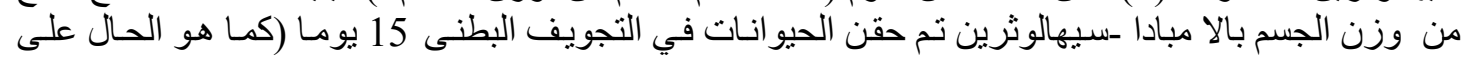

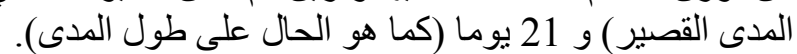

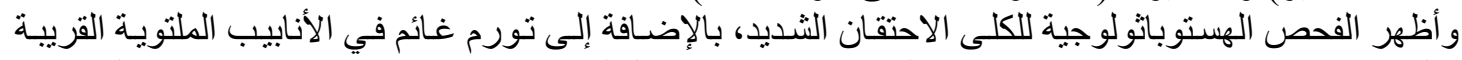

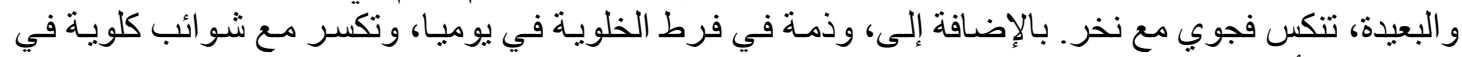

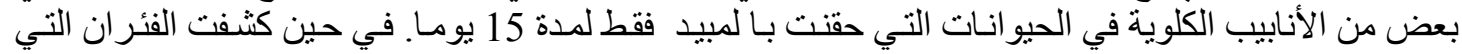

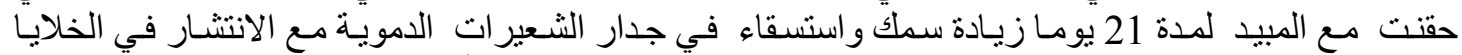

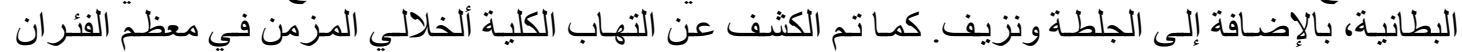

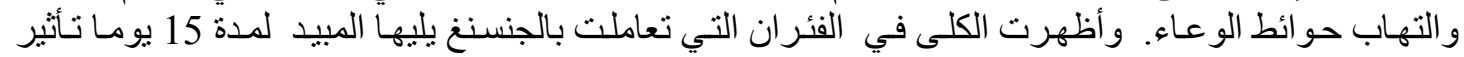

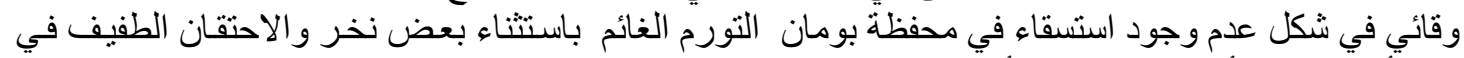

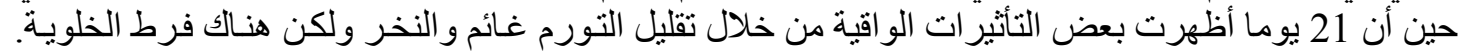

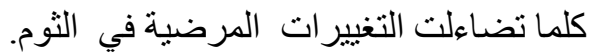

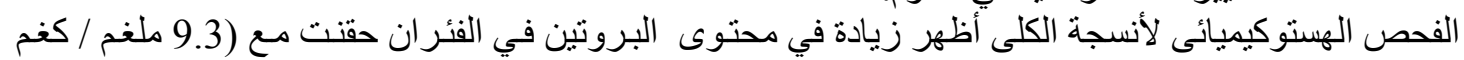

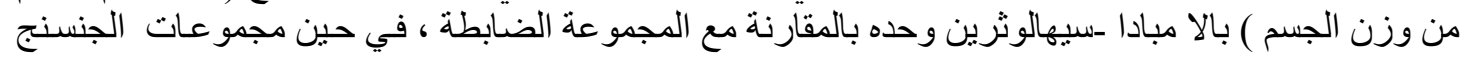
و الثوم محتوى البروتين شبه طبيعي.

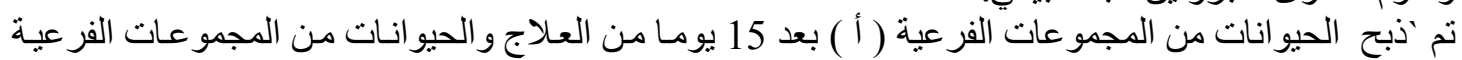
(ب) بعد 21 يوما من العلاج .وتعرض عنات عينات أنسجة الكلى للفحوص الهينو بانولوجية و الهستو كيميائية 